\title{
Gender and Ethnicity Differences Manifested in Chemistry Achievement and Self-Regulated Learning
}

\author{
Arsaythamby Veloo ${ }^{1}$, Lee Hooi Hong ${ }^{2} \&$ Seung Chun Lee ${ }^{1}$ \\ ${ }^{1}$ School of Education and Modern Languages, Universiti Utara Malaysia (UUM), Malaysia \\ ${ }^{2}$ Kedah Matriculation College, Changlun, Kedah, Malaysia \\ Correspondence: Arsaythamby Veloo, School of Education and Modern Languages, Universiti Utara Malaysia, \\ 06010 Sintok, Kedah, Malaysia. E-mail: arsay@uum.edu.my
}

Received: February 27, 2015 Accepted: March 28, 2015 Online Published: July 27, 2015

doi:10.5539/ies.v8n8p1 URL: http://dx.doi.org/10.5539/ies.v8n8p1

\begin{abstract}
The aim of this study is to examine whether gender and ethnicity differences are manifested in chemistry achievement and self-regulated learning among a matriculation programme students in Malaysia. The result of students' midterm chemistry exam was used as the measure of chemistry achievement. The information of self-regulated learning was collected by using a survey questionnaire that was adapted from the Motivated Strategies and Learning Questionnaire (MSLQ). Random sampling method was utilized to select 358 students of Matriculation Science One-Year Programme. The results of gender differences showed that male students obtained significantly higher achievement in chemistry compared to female counterparts whereas there was no significant gender difference in self-regulated learning. The results of ethnicity differences confirmed that there was a significant difference in chemistry achievement between Malay and Chinese students, Malay and Indian students, respectively. In terms of self-regulated learning, however, a significant difference was found only between Malay and Indian students. The findings suggest that science instructors in higher education institutions utilize the MSLQ to get the information about students' self-regulatory level and motivational level, design a "gender-based initiative" to address the lower science achievement of female students, and be ready to having learning resources and pedagogical practices available for a learning condition with diverse groups of different ethnicities.
\end{abstract}

Keywords: chemistry achievement, self-regulated learning, gender difference, ethnicity difference

\section{Introduction}

The Matriculation Programme is one of the Malaysian Education programmes which are open to the students who completed their secondary school programme with good performance in the Malaysian Certificate of Education (SPM). This programme, which is managed by the Matriculation Division in the Ministry of Education, Malaysia, includes One-Year Science Programme and Two-Year Science Programme, Accountancy Programme and Technical Engineering Programme. Students who get the offer from the Matriculation Division may choose one of the programmes based on their SPM result and their interest. The objectives of Matriculation Programme are focused on generating the knowledgeable, creative and competitive students who are able to fulfil the needs of higher learning institution in the fields of science and technology professions. These objectives are in line with the Malaysia National Education Blueprints 2013-2025 that aim to prepare young Malaysians for the challenges of the $21^{\text {st }}$ century.

The Chemistry Unit of the Matriculation College (MC) in Malaysia has introduced and run a few academic programmes such as "Chemistry Excellent Class", "Consultation of Chemistry", and "Score Chemistry Workshop". Although the primary goal of these programmes is to produce the excellent students who will be evidenced in their chemistry results of Matriculation Programme Semester Exam, chemistry plays an important part in all of the other natural sciences, basic and applied. The rapid development in chemistry contributes towards vast development in various fields including medicine, engineering, biotechnology and agriculture. Chemistry is sometimes called a central science because it connects physics with other natural sciences such as geology and biology.

Current syllabus of chemistry in the One Year Science Programme in Matriculation College covers the basic 
principles of physical and organic chemistry. The syllabus (Physical \& Organic Chemistry) is similar to the A-Level Syllabus and is used in two semesters or one year. Teaching and learning of chemistry currently conducted in Matriculation College intend to provide a platform for the acquisition and dissemination of knowledge, enriching mastery of concepts and application of theories in chemistry. Hence, The Matriculation science students can apply for the universities that require A-Level or equivalent level of subjects. The curriculum of Matriculation chemistry programme is expected to fulfill the National Science Education Philosophy by focusing on the development of competitive, dynamic, robust and resilient individuals who are able to master scientific knowledge and technological competency.

\subsection{Chemistry Achievement of Malaysian Students}

Students' achievement has always been a concern of Malaysian government and parents alike. When Malaysia first participated in Trends in International Mathematics and Science Study (TIMSS) in 1999, the average score of students was higher than the international one in both mathematics and science. By 2007, however, the students' performance had slipped to below the international average in both mathematics and science with a commensurate drop in ranking. Critically, $18 \%$ and $20 \%$ of Malaysian students failed to meet the minimum proficiency levels in mathematics and science in 2007 , a two to fourfold increase from $7 \%$ and $5 \%$ respectively in 2003. These students were identified as possessing only limited mastery of basic mathematical and scientific concepts. The 2011 TIMSS showed no improvement of the Malaysia's ranking and average scores in mathematics and science. The Malaysia's TIMSS ranking in mathematics fell from 20th in 2007 to 26th in 2011 while science ranking from 21th in 2007 to 32nd in 2011 (Mullis, Martin, Foy, \& Arora, 2012).

The results from Programme for International Student Assessment (PISA) 2009 (the first time Malaysia participated in this assessment) were also discouraging, with Malaysia ranking in the bottom third of 74 participating countries which include the membership countries of Organization for Economic Co-operation and Development (OECD). The Executive Summary of Malaysia Education Blueprints 2013-2025 pointed out that almost $60 \%$ of the 15 -year-old Malaysian students who participated in PISA failed to meet the minimum proficiency level in mathematics, while $44 \%$ and $43 \%$ did not meet the minimum proficiency levels in reading and science respectively. Considering a difference of 38 points on the PISA scale is equivalent to one year of schooling, this outcome indicated that 15-year-olds in Malaysia fell behind the counterparts in Singapore, South Korea, Hong Kong, and Shanghai by 3 or more years of schooling in these subjects. The results of the latest 2012 PISA were little better than the previous ones: Malaysian students scored 421 in mathematics, 398 in reading and 420 in science respectively, which were below the global average score of 494 in mathematics, 496 in reading and 501 in science respectively. The performance is still placed at the bottom third as in Australian Council for Educational Research 2009 (ACER, 2011; Kulasagaran, 2013). Of particular note are the results of 2011 TIMSS which indicated that there was a statistically significant difference in average science scores of $8^{\text {th }}$-grade students in terms of gender. The average score of female students who participated in 2011 TIMSS is higher than male students (Mullis, Martin, Foy, \& Arora, 2012). The similar results also were found in the results of PISA 2009+ for Malaysia participants who also favored female students (ACER, 2011).

The chemistry result of MC manifested in recent three years is in declining trend. The average chemistry grade is 3.22 from total of 4.00 in session 2010/2011. The average is dropped to 3.21 for the next session and 3.18 in session 2012/2013. Given that the result is the minimum target that MC Chemistry Unit tries to achieve, the declining trend of the results in chemistry has raised the issue of the effectiveness of teaching and learning process in MC. There have been numerous researches that examined the factors that affect students' academic achievement in general or in a particular course such as basic science and chemistry. Specifically, chemistry achievement has been found to be influenced by the factors such as learning environment (Adesoji \& Olatunbosun, 2008), motivation, students' anxiety level (Akbaş \& Kan, 2007) and students' learning strategies (Dunlosky et al., 2013).The Science Programme of MC is a case in point. The students have been put at a disadvantage in terms of learning environment. The class schedule is fully packed from 8 am to 4 pm with an hour break as resting time. There are many core subjects including chemistry which push the students to acquire their content knowledge with less effective modules and scant guidelines on how to study science effectively.

On the other hand, the factors of motivation and strategies have much to do with students' initiative to learn and enhance their content knowledge and higher academic skills. Specifically motivational beliefs (e.g., self-efficacy or interest) and use of self-regulation strategies are the core components of most self-regulated learning models (Cleary \& Callan, 2013). Students who have potential to successfully engage in science tasks usually have strong self-efficacy and exhibit high interest in completing science tasks (Usher \& Pajares, 2008). Those who report systematic use of metacognitive and learning strategies typically reach overall academic achievement including higher literacy skills and math skills (Ness \& Middleton, 2012). Just as Bembenutty (2007) indicates, however, 
there is a dearth of studies in the self-regulation of learning which investigated individual differences such as gender and ethnicity of students. This study aimed to fill the gap by analyzing whether gender and ethnic differences exist regarding students' chemistry achievement and self-regulated learning. Thus, the main research questions guiding our investigation were: (1) Is there a difference between male and female students in terms of chemistry achievement and self-regulated learning? (2) Is there a difference among different ethnic groups of students (Malays, Chinese \& Indians) in terms of chemistry achievement and self-regulated learning?

\subsection{Self-Regulated Learning (SRL)}

Self-regulated learning (SRL) or self-regulation refers to individual learner's ability to understand and control one's own learning environment. Generally it is conceptualized as a cyclical and multi-dimensional process where purposeful efforts are involved such as behavioral and cognitive control and optimization of learning in a particular context (Pintrich, 2000; Zimmerman, 2000). Specifically it is a metacognitive process where students plan before initiating a task and monitor their performances online and evaluate whether their learning approach has been effective after finishing the task. It comes as no surprise that students who practice self-regulated learning are able to facilitate the development of their behavioral skills and habits that will further assist them in learning effectively in other contexts. They are able to apply appropriate learning strategies in order to improve their academic outcomes (Al Khatib, 2010; Cheng, 2011; Radovan, 2011).

Research on applying self-regulation to education began as an extension of psychological investigations into self-control in behavioral problems and its development among adults and children. One of the factors to drive the SRL research toward this direction is studies suggesting that SRL factors such as self-regulation and motivation were as important as students' skills and abilities in students' academic achievement (Zimmerman, 2001). Not only are these factors seen as a mechanism to help explain differences in academic achievement among students, but it functions as a means to improve academic achievement. Particularly the studies of secondary education have shown that SRL factors predict academic achievement (Wolters, 1999) because of autonomy of learning as well as increased contextual complexity. Besides, there have been many studies of SRL which indicated that students equipped with higher level of knowledge and effective use of SRL strategies have been successful in obtaining higher literacy abilities (Schunk \& Zimmerman, 2007), mathematics (Metallidou \& Vlachou, 2010; Belal-Rabab'h \& Arsaythamby, 2015), and science skills (Cleary et al., 2008).

Various models of SRL have been introduced, but all share the assumption that students can actively employ self-regulatory abilities regarding their cognition, motivation, or behavior in order to acquire knowledge, enhance performance and achieve educational goals (Zimmerman, 1989). For instance, a cyclical model proposed by Zimmerman, Bonner, and Kovach (1996) comprises four correlated processes: self-evaluating and monitoring, goal setting and strategic planning, strategy implementation and monitoring, and strategic-outcome monitoring. This model is recognized as cyclical because students are supposed to return to the first phase of the framework and continue to make another assessment of their strategic performance levels. Pintrich's (2000) model, which is recognized as a social-cognitive framework, has almost same four phases of self-regulation as the Zimmerman's. The phase one (i.e., forethought, planning \& activating) involves a process where students analyze the learning task and set specific goals to accomplish the task. The phase two (i.e., monitoring) concerns various processes where students monitor the progress and effectiveness of the learning strategies to complete the particular task. During the phase three (i.e., control), students attempt to control different aspects of cognition, motivation, behaviors and contextual factors based on the monitoring phase. In the phase four (i.e., reaction \& reflection), students practice self-evaluation and self-reflection about their performance in the learning task. It is important to note that this model presumes that the four phases are not hierarchically or linearly ordered but are interactively working. Each of the phases may occur at any time students actively engage in the learning task. There are learning situations in which students may engage in some but not all of the phases or they may simultaneously engage in more than one.

\subsection{Gender Differences Manifested in Chemistry Achievement and SRL}

Mixed results have been revealed regarding the gender differences in science achievement. Science is meant to include physics, chemistry, biology or a composite of any areas of scientific knowledge. In the comparison study of 2011 Trends in International Mathematics and Science Study (TIMSS), Amelink (2009) reported that American male and female fourth-graders did not show a significant difference in their science performances, but male eighth-graders represented significantly better performances than female counterparts overall in science (i.e., physics, biology \& earth science) except chemistry. This phenomenon has been consistent based on the American data of the National Assessment of Educational Progress (NAEP) from 1969 to 1999 which found that males in the primary and middle schools outperformed females on science achievement tests, and the data of 
1999 TIMSS which indicated that males outperformed females significantly in science tests. In addition, the result from Advanced Placement Program (APP) for American high school students in 2007 confirmed that male students scored higher on 35 tests including chemistry test than female students. The percentage of male students receiving a score of 5 (i.e., Extremely well qualified) in APP chemistry test participants is $18 \%$ while the one of female students is $11 \%$. This phenomenon seemed to be extended to the American higher institutions. Obrentz (2012) reported that there was a significant difference in the final chemistry grades between university males and females. Male students scored better than female students.

The cross-cultural evaluation of science achievement conducted by International Evaluation of Education Achievement (IEA) also pointed out the same trend of lower female achievement compared with male students. The First and Second International Science Study (FISS \& SISS), and Third International Mathematics and Science Study (TIMSS) revealed that there has been consistent outperforming of male students in the written achievement tests of every science subject (Amunga, Amadalo, \& Musera, 2011). They also found out male students outperformed female students in chemistry in 32 secondary schools in Western Province of Kenya. The chemistry results of male students had the upper hand from the year of 2005 until 2009 compared with female students. Likewise, Male students' higher performances in chemistry have also been seen in other countries such as Nigeria and Kenya. Ezeudu and Obi-Theresa (2013) investigated the effects of gender and location on students' chemistry achievement in a local government area in Nigeria. The findings showed that chemistry achievement of male students was significantly higher than the one of female students in both rural and urban areas. The same phenomenon was found in an Ethiopian college in which Tenaw (2013) investigated the gender difference of 100 students in terms of chemistry performance. The finding showed that male students are better performers than female in chemistry.

It is noteworthy, however, that there have been the other line of research which indicated no significant difference between genders in science performance. Take Oludipe's (2012) study for instance. It reported that there was no significant difference in basic science achievement between male and female junior secondary school students in Nigeria. This study was based on a quasi-experimental design which had a treatment period of cooperative learning strategy in basic science class. The same result was also found by Afuwape (2011) who used an ex post facto research design. The performance of secondary school male and female students in basic science had no significant difference. Given that there were some other studies reporting the disadvantaged position and low interest of male students in science subjects (Omoniyi, 2006), eventual achievement by learners seem to be closely related to personal efforts, cognitive abilities, and pedagogical practices than gender variable (Olukemi, 1998).

There are many researches that revealed gender differences in Self-Regulated Learning (SRL). Al Khatib's (2010) study involving 404 United Arab Emirates (UAE) college students indicated that the UAE female college students displayed significantly higher means of test anxiety, self-efficacy and self-regulated learning than the male counterparts. Even though these female students revealed higher level of test anxiety, they performed better than the male students probably because they enjoyed learning more and made more efforts than the male students due to their strong motivation to pursue college education. DiBenedetto and Bembenutty (2011) also found that female students show higher self-regulation ability than male students in a college biology course in New York. Bidjerano (2005) also found that American female college students outperformed male students in terms of their use of rehearsal, organization, metacognition, time management skills, elaboration, and effort. This result is keeping in line with previous studies representing the better performance of female students in terms of strategy use (Niemivirta, 1997). Female students do not only tend to be more willing to participate in the report of their strategy use compared to male students, but they seem to be more reflective on their learning experiences and their strategy use, due to the innate nature of their gender disposition. Even primary and secondary school female students demonstrated the same distinguishing features of self-regulated learning, i.e., the girls tend to make much more use of self-monitoring, goal setting, planning and structuring of their study environment than boys among 14 self-regulatory learning strategies (Zimmerman \& Martinez-Pons, 1990).

Nevertheless, it cannot be denied that there have been some conflicting research findings against the female students' better performance in SRL. Take a Malaysian research using secondary school students for instance. Muhamad-Ikhwan, Ong, and Sadiah (2009) reported that there is no significant gender difference in SRL if its two components, i.e., motivation and learning strategies in MSLQ, are taken as whole, even though female students showed a higher mean score when both are measured separately. Obrentz (2012) went on to report that male students are the better user of self-regulated learning compared to female students in terms of self-efficacy and critical thinking. Meanwhile, the result of the research also pointed out that there is no significant main effects of gender on elaboration. In general, male students are reported to have significantly higher total 
motivation scores than female students in relation to the learning of chemistry. Summing up, most of the researches of SRL have focused on secondary school students or students in higher education institutions. Even though mixed results have been found out in the relationships among SRL, chemistry achievement and gender, gender differences have been consistently reported. Female students generally indicated higher ability of SRL than male students.

\subsection{Ethnicity Differences Manifested in Chemistry Achievement and SRL}

Ethnicity differences are expected in chemistry achievement and self-regulated learning because different characteristics in a specific ethnic culture bring various styles of students' ideas, values and strategies to their learning processes (Turingan \& Yang, 2009). In general, there has been less research on ethnic difference in self-regulated learning than gender difference. Obrentz (2012) argues that although the ethnic discrepancy in science is often reported (Pintrich \& Zusho, 2007), explaining why these differences exist is difficult. It comes as no surprise that few learning gains have been yielded over the years to close the performance gaps. It seems that the reason Nelson (1996) pointed out has not been considered in the studies to compare ethnicity difference: little consistency can be found in the definition of ethnic groups and the number of ethnic groups for investigation. There have been cases where the differences which were attributed by ethnic difference proved to be an outcome of exposure to science materials or learning strategies employed in secondary schools.

Kohlhaas, Lin, and Chu (2010) revealed that there are significant differences in science achievement between ethnic groups of fifth graders in America. With a skewed ethnic distribution in the number of participants (58\% Whites, 19\% Hispanic, 11\% African American, 7\% Asian, and 6\% others), their research showed that the rank order of science scores were White, Asian, Hispanic, and African American in terms of ethnicity. Among the three variables which significantly contribute to their science performance, ethnicity (16 points) proved to have the most significant effect compared to the other two variables (gender: 3 points; poverty: 14 points). Kohlhaas, Lin, and Chu (2010) concur on the main culprit(s) for this situation. The lower science performance among ethnic minorities can be attributed to any or all of the following factors such as "inadequate learning opportunities in the areas of curriculum, instruction, assessment, teacher education, school organization, educational policies and a failure to connect with students' homes and community environments"(p. 3).

Using the MSLQ as the survey instrument to assess SLR skills, Bembenutty (2007) investigated gender and ethnic differences in the relationships between academic performance, self-regulation and motivational elements in an American university, and Turingan and Yang (2009) conducted a cross-cultural comparison of SRL skills between Filipino and Korean college students. Bembenutty (2007) found that minority undergraduate students (i.e., African Americans, Asian Americans, Hispanics, and Native Americans) in the university displayed lowest SRL in an examination, compared to the majority students (i.e., Caucasian ones). Specifically, the minority students showed lower self-efficacy level than Caucasian students. Turingan and Yang (2009) found that the SRL skills of Filipino college students were higher than the ones of Korean college students.

The outcome of these two studies should not be interpreted as suggesting that a certain ethnic group of students is inherently different in ways that lead them to achieve better academic performance compared with other ethnic group of students. In the former study, the socialization process and classroom contexts such as academic tasks, reward structures, instructional methods, and instructor behaviors among majority and minority students should be taken into account whereas in the latter study, cultural factors, educational background, college entrance process between Filipino and Korean students should be considered in the picture of ethnicity difference. In addition, the results of the latter study seemed to be further confounded by the gender factor, i.e., most of the Korean students were males whereas most of the Filipino students were females.

\section{Methodology}

\subsection{Research Framework}

This research employs a quantitative research method by using a students' midterm chemistry exam result (PSPM) as the measure of chemistry achievement and a survey questionnaire as the one of self-regulated learning. The exam result was collected from, and the questionnaire was administered to, the MC One-Year Science Programme students. The data were analyzed by using independent-sample $t$-test and one-way ANOVA according to research questions. There are four subscales in the survey questionnaire to measure the participants' SRL level: task value, self-efficacy, elaboration and critical thinking. Students' demographic factors, which are gender and ethnicity, are independent variables, and their chemistry achievement and self-regulated learning are dependent variables. 


\subsection{Population and Sampling}

1790 students took Matriculation Science One Year Programme in the MC in the session of 2013/2014. Female students amounted to1,274 (71\%) and male students 520 (29\%) among them. Generally MC students come from three ethnic groups, i.e., Malay, Chinese and Indian. The majority of them are Malays because the vision of Matriculation Programme is to produce excellent and competitive Bumiputera (i.e., ethnic Malays \& other indigenous peoples) students in higher education. The Malay students made up 1,597 (89\%) of the college's population whereas Chinese students and Indian students amounted to $87(5 \%)$ and $106(6 \%)$ respectively. For this study, data were collected from 358students from the 2013/2014cohort of MC students based on random sampling. Of the participants, $259(72 \%)$ were female students and $99(28 \%)$ were male students. In terms of ethnicity, the majority of the students were Malays 310 (87\%), 22 (6\%) were Chinese and 26 (7\%) were Indians.

\subsection{Motivated Strategies for Learning Questionnaire}

In order to assess the levels of SRL of the Matriculation Science One Year Programme students, a survey questionnaire is adapted from the Motivated Strategies for Learning Questionnaire (MSLQ) which was designed by Pintrich, Smith, Garcia, and McKeachie (1993) as a tool of self-report by post-secondary students, specifically to assess college student's motivation orientations and self-regulated learning for specific course.

The MSLQ has 15 subscales which are divided into two sections. The first section is motivation scales (13 items) and the second section is self-regulated learning strategies (10 items). MSLQ is a completely modular instrument, and thus the subscales can be used together or individually, depending on the needs of the researcher who is interest in measuring the motivation and self-regulated learning of respondents (Talyor, 2012). The adapted survey questionnaire employed a 7-point Likert scale ranging 1 to 7, from "Not at all true of me" (1), "Not true for me" (2), "Somewhat not true of me" (3), "Neutral" (4), "Somewhat true of me" (5), "True of me" (6) to"Very true of me" (7). The total number of items adapted from MSLQ for this research was 23 and these items were divided into four subscales of SRL for the study. The adapted survey questionnaire SRL has a Cronbach's alpha value of 0.89 and each subscale has the following alpha values: Task Value (0.81), Self-efficacy (0.81), Elaboration (0.77) and Critical Thinking (0.88).

The number of each item comprising the four subscales in the survey questionnaire is shown in Table 1.

Table 1. Items of each subscale in the survey questionnaire

\begin{tabular}{lcc}
\hline Main Scale & Subscale & Items of Each Subscale \\
\hline \multirow{2}{*}{ Motivation Scale } & Task Value (6 items) & $1,4,7,9,10,11$ \\
& Self-Efficacy (7 items) & $2,3,5,6,8,12,13$ \\
\multirow{2}{*}{ Learning Strategies Scales } & Elaboration (5 items) & $17,18,19,21,23$ \\
& Critical Thinking (5 Items) & $14,15,16,22,20$ \\
\hline
\end{tabular}

\section{Findings}

\subsection{Research Question 1: Chemistry Achievement and SRL Based on Gender}

The statistical analyses of the research question 1 were based on independent-sample $t$ tests. Firstly, they examined whether there was a significant difference between male and female students in terms of chemistry achievement and self-regulated learning. The results presented in Table 2 shows that there is significant difference ( $\mathrm{t}(356)=2.20, p<.05, d=0.30)$ and size effect was moderatebetween male and female students in chemistry achievement. The score of male students (58.17\%) is higher than female students $(53.41 \%)$ in chemistry achievement.

Table 2. Chemistry achievement based on gender

\begin{tabular}{lllllll}
\hline Gender & $\mathrm{N}$ & Mean & $\mathrm{SD}$ & $\mathrm{df}$ & $\mathrm{t}$ & $\mathrm{p}$ \\
\hline Male & 99 & 58.17 & 19.49 & 356 & 2.20 & $.03^{*}$ \\
Female & 259 & 53.41 & 17.85 & & & \\
\hline
\end{tabular}

$* \mathrm{p}<.05$. 
By contrast, however, the results reported in Table 3 indicate that there is no significant difference $(\mathrm{t}(356)=.04$, $p>.05, d=0.05$ ) and size effect was small between male students and female students in terms of self-regulated learning. This finding showed that there is no difference between male and female students in the self-regulated learning.

Table 3. Self-Regulated learning based on gender

\begin{tabular}{lllllll}
\hline Gender & $\mathrm{N}$ & Mean & $\mathrm{SD}$ & $\mathrm{df}$ & $\mathrm{t}$ & $\mathrm{p}$ \\
\hline Male & 99 & 4.97 & .84 & 356 & .04 & .97 \\
Female & 259 & 4.94 & .80 & & & \\
\hline
\end{tabular}

$\mathrm{p}>.05$.

\subsection{Chemistry Achievement and SRL Based on Ethnicity}

In order to address Research Question 2, all scores of chemistry achievement were submitted to one-way analysis of variance (ANOVA) (Table $4 \& 5$ ). Table 4 indicates that a significant difference was found for different ethnic groups of students, $F(2,355)=58.54, p<.05$.Post hoc test shows that there was a significant difference $(\mathrm{p}<.05)$ between Chinese-Malay, and Indian-Malay students, but not significant between Chinese and Indian students $(p>.05)$, in chemistry achievement. Even though the number of participants was small, other ethnic groups of students significantly outperformed Malay students. The score of the Chinese students (85.23\%)was the highest in PSPM chemistry among all ethnicity groups while the Malay students' score $(50.46 \%)$ was the lowest one in chemistry among all ethnicity groups.

Table 4. Chemistry achievement based on ethnicity

\begin{tabular}{lccccccc}
\hline & $\mathrm{N}$ & Mean & $\mathrm{SD}$ & $\mathrm{df1}$ & $\mathrm{df2}$ & $\mathrm{F}$ & $\mathrm{p}$ \\
\hline Malay & 310 & 50.46 & 15.57 & 2 & 355 & 58.54 & $.00^{*}$ \\
Chinese & 22 & 85.23 & 9.09 & & & & \\
Indian & 26 & 76.62 & 13.76 & & & & \\
\hline
\end{tabular}

$* \mathrm{p}<.05$.

Table 5 reports that there was a significant difference between different ethnic groups of students in terms of SRL, $F(2,355)=4.76, p<.05$. A post-hoc test shows that a significant difference was found only between Malay and Indian students $(p<.05)$ but not significant between Chinese-Malay and Chinese-Indian students $(p>.05)$ in Self-Regulated Learning. The score $(\mathrm{M}=5.41, \mathrm{SD}=0.81)$ of the Indian students was the highest in SRL compare to score of Chinese students $(M=5.32, S D=0.93)$ and Malay students' $(M=4.90, S D=0.79)$ in chemistry.

Table 5. Self-regulated learning based on ethnicity

\begin{tabular}{lccccccc}
\hline & $\mathrm{N}$ & Mean & $\mathrm{SD}$ & $\mathrm{df1}$ & $\mathrm{df} 2$ & $\mathrm{~F}$ & $\mathrm{p}$ \\
\hline Malay & 310 & 4.90 & .79 & 2 & 355 & 4.76 & $.00^{*}$ \\
Chinese & 22 & 5.32 & .93 & & & & \\
Indian & 26 & 5.41 & .81 & & & & \\
\hline
\end{tabular}

$* p<.05$.

\section{Discussion and Conclusion}

\subsection{Chemistry Achievement and Self-Regulated Learning Based on Gender}

The score of male students is higher than female students in chemistry exam, even though both the majority of female and male students are placed at average level in terms of chemistry grade. This finding is consistent with 
previous research that also found out male students' higher chemistry achievement than female students (Amelink, 2009; Amunga, Amadalo, \& Musera, 2011; Ezeudu \& Obi-Theresa, 2013; Obrentz, 2012; Tenaw, 2013). In particular, American data on students' performance in science support this consistent trend. Not only do the male students show better performance than female students in primary and secondary schools, but they outperform females in tertiary education. Based on the meta-analysis of gender differences in science achievement, Amelink (2009) specifically pointed out that American male students enhanced their science proficiency than their female counterparts in an increasing manner between 8th to 12th grades (equivalent to Form 1 to Form 5 in secondary school in Malaysia education system). This trend is also echoed in the cross-cultural evaluation of science achievement such as IEA, FISS, SISS, and TIMSS.

Nonetheless, mixed results should be taken into account to resolve the issue of gender difference in science achievement including chemistry. They suggest that discrepancy between conflicting results could be explained by personal variables such as students' cognitive abilities, motivation and efforts (Olukemi, 1998), and pedagogical variables such as the teaching strategies and gender-biased stereotypes of teachers (Oludipe, 2012). Even the studies whose outcomes are in favor of male students can be interpreted from a different perspective. Take Tenaw's (2013) study for instance. In this research, the lower chemistry achievement of female students in an Ethiopian college was attributed to the "lack of basic study skills and inability to handle materials necessary in the examination" (p. 23). These problems, however, apply to male college students as much as to female counterparts.

The result of no gender difference in self-regulated learning in the current study could be caused by the existence of more complicated relationships of multiple variables between genders. In general, however, female students have been reported to have higher ability of self-regulated learning than male students but mixed results have been found out in the relationships among chemistry achievement, SRL and gender. Female students seem to be good at strategy use and reflective activities whereas male students appear to be strong in self-efficacy and critical thinking. A critical point to note at this juncture, however, is the significance of value which students of each gender places on the prospective jobs rather than on their personal competence or self-efficacy (Eccles, 2007). Eccles (2007) reported that men and women are socialized from early in life to pursue different occupational paths for them. Thus, if female students are to find value in pursuing science-related fields, they need to be provided the pertinent information and instruction on these occupations.

\subsection{Chemistry Achievement and Self-Regulated Learning Based on Ethnicity}

The One-Way ANOVA test shows that there is a significant ethnicity difference in chemistry achievement. The chemistry mean scores, in order of ethnic group from the highest to lowest scores, were Chinese (85.23), Others (78.00), Indians (76.62), and Malays (50.46). The descriptive statistics of chemistry grade shows almost the same ethnicity difference in chemistry achievement. Only $7.5 \%$ of Malay students scored grade A to grade B+, which is considered as high achieving according to Matriculation College system. The percentage of high achieving group in Chinese and Indians was $86.4 \%$ and $84.6 \%$ respectively. $39.7 \%$ of Malay students and 3.8\% of Indian students belonged to the low achieving group where the grade ranges from grade C-to grade $\mathrm{F}$. There are no such cases in Chinese.

A few interpretations can be made for the outcome of this study which supports the ethnicity difference in chemistry achievement. The first factor is motivation. The non-Malay students in Malaysia such as Chinese and Indian students in the matriculation programme need to maintain their highest level of academic achievement including chemistry to ensure they are able to be enrolled in the courses they wish to study in the public universities because the entrance to public university courses gets tougher for non-Malay students in recent years (Kulasagaran, 2013). The second consideration has much to do with the learning strategies students implement due to their cultural preferences (Nelson, 1996) or individual choices. These learning strategies are likely to be more closely linked to students' academic performances than other factors such as lower family income or lack of preparation or motivation. The third aspect worthy of notice is teachers' failure to provide adequate instruction for students with diverse cultural and academic backgrounds (see Bembenutty, 2007).

In the same vein, the current study confirmed that there is significant ethnicity difference in self-regulated learning. The outcome of ethnicity difference in chemistry achievement is echoed in this result of ethnicity difference in self-regulated learning. However, the significant difference was found only between Malay and Indian students. Indian students have significantly higher self-regulated learning ability than Malay students but Chinese students also indicated higher level of self-regulated learning than Malay students. As Turingan and Yang (2009) argued, the differences in self-regulated learning ability between different ethnicity could be primarily explained as cultural factors such as social expectations, values, beliefs towards college education, and 
respect for authority. These cultural factors are pertinent to the idea of instructional congruence which Lee and Fradd (1998) promoted, "a process to reconcile academic content with students' cultures and languages" (cited in Kohlhaas, Lin, \& Chu, 2010, p. 3).

\subsection{Conclusion and Pedagogical Implications}

This study provides a general picture about how the chemistry achievement and self-regulated learning level of Malaysian Matriculation College students go in terms of their gender and ethnicity. In relation to gender, a significant difference was found in chemistry achievement (i.e., better performances of males), but no difference was detected in self-regulated learning level. In terms of ethnicity, Indian and Chinese students outperformed Malay student in both chemistry and self-regulated learning level.

Implications need to be provided in light of potential limitations of this study. The results of this study should not be extended to the interpretation of the general features of Malaysian Matriculation Programme students' academic achievement in terms of gender and ethnicity. This study was based only on a students' midterm chemistry exam (PSPM) result and an adapted version of MSLQ. In addition, the result of PSPM does not always appropriately capture the students' science proficiency including chemistry. As noted earlier, KMC students were placed in a disadvantaged learning environment in terms of class schedule and availability of effective modules and learning strategies.

With these limitations in mind, a few suggestions can be made to the instructors of science disciplines working in higher institutions and education policy makers attempting to enhance the science proficiency in tertiary education. First, utilize the MSLQ to get the information about students' self-regulatory level and motivational level. This information goes a long way to improving their achievement in science as well as predicting it. This information can primarily help instructors to integrate pertinent teaching approaches into the science classroom in order to enhance students' learning process. On the other hand, this information can be used as a significant tool to identify at-risk or vulnerable students in science classes. The result from the questionnaire can set alarms ringing for instructors to plan and execute precautionary actions such as consultation hours and motivation programmes.

Second, design a "gender-based initiative" (Amerlink, 2009, p. 27) to address the lower science achievement of female students by focusing on increasing the knowledge and skills of females in specific content areas of science which may put them at a disadvantage. This process will enable females to build self-efficacy in the application of science knowledge and skills. The effect of this initiative can be doubled if instructors are willing to correct gender biased stereotypes which have a direct bearing on teachers' attitudes, pedagogical practices and strategies toward female students. However, the success of this initiative is highly dependent on parents' expectations for science education and science careers which will determine their female children's course of life. Thus, instructors need to inform parents of female students about future career opportunities in science areas and necessary academic preparation for these areas.

Lastly, be ready to having learning resources and pedagogical practices available for a learning condition with diverse groups of different ethnicities. On the one hand, instructors could create a classroom environment to encourage a specific group of potentially low-achieving students to develop the systematic use of metacognition and relevant learning strategies on which higher literacy skills and math skills are predicated. The development process can be expedited by the demonstration of different kinds of self-regulated learning strategies and the use of intriguing tasks to incorporate real world problems and science content, which is the essence of "connected science" (Bouillion \& Gomez, 2001). On the other hand, instructors could promote group discussion and problem solving practices to enhance the level of self-regulated learning. A group of students with diverse abilities and ethnicities, in its ideal condition, can help one another increase their level in self-efficacy, elaboration skills and critical thinking for meaningful learning. Instructors maintain primary responsibility in forming the best possible groups of students for the significant group dynamics to emerge.

\section{References}

ACER (Australian Council for Educational Research). (2011, December 16). ACER releases results of PISA $2009+$ participant economies. Retrieved December 1, 2013, from http://www.acer.edu.au/media/acerreleases-results-of-pisa-2009-participant-economies/

Adesoji, F. A., \& Olatunbosun, S. M. (2008). Student, teacher and school environment factors as determinants of achievement in senior secondary school chemistry in Oyo State, Nigeria. The Journal of International Social Research, 1(2), 13-34.

Afuwape, M. O. (2011). Students' self-concept and their achievement in basicscience. International 
Multidisciplinary Journal, Ethiopia, 5(4), 191-200. http://dx.doi.org/10.4314/afrrev.v5i4.69276

Akbaş, A., \& Kan, A. (2007). Affective factors that influence chemistry achievement (motivation \& anxiety) and the power of these factors to predict Chemistry achievement. Journal of Turkish Science Education, 4(1), 10-19.

Al Khatib, S. (2010). Meta-cognitive self-regulated learning and motivational beliefs as predictors of college students' performance. International Journal for Research in Education, 27(8), 57-71.

Amelink, C. (2009). Literature overview: Gender differences in science achievement. Retrieved December 1, 2013, from http://www.engr.psu.edu/awe/misc/arps/arp_genderdifferencesscience_overview.pdf

Amunga, J. K., Amadalo, M. M., \& Musera, G. (2011). Disparities in chemistry and biology achievement in secondary schools: Implications for vision 2030. International Journal of Humanities and Social Science, l(18), 226-236.

Belal-Rabab'h, S., \& Arsaythamby, V. (2015). Prediction of Mathematics Learning Strategies on Mathematics Achievement among 8th Grade Students in Jordan.Asian Social Science, 11(2), 276-283 http://dx.doi.org/10.5539/ass.v11n2p276

Bembenutty, H. (2007). Self-regulation of learning and academic delay of gratification: Gender and ethnic differences among college students. Journal of Advanced Academics, 18(4), 586-616. http://dx.doi.org/10.4219/jaa-2007-553

Bidjerano, T. (2005). Gender differences in self-regulated learning. Retrieved December 14, 2013, from http://eric.ed.gov/?id=ED490777

Cheng, C. K. (2011). The role of self-regulated learning in enhancing learningperformance. The International Journal of Research and Review, 6(1), 1-16.

Cleary, T. J., Platten, P., \& Nelson, A. (2008). Effectiveness of the self-regulation empowerment program (SREP) with urban high school youth: An initial investigation. Journal of Advanced Academics, 20(1), 70-107. http://dx.doi.org/10.4219/jaa-2008-866

DiBennedetto, M. K., \& Bembenutty, H. (2011). Within the pipeline: Self-regulated learning and academic among college students in science courses. Paper presented at American Educational Research Association, New Orleans, Louisiana. Retrieved December 14, 2013, from http://files.eric.ed.gov/fulltext/ED518505.pdf

Dunlosky, J., Rawson, K. A., Marsh, E. J., Nathan, M. J., \& Willingham, D. T. (2013). Improving students' learning with effective learning techniques: Promising directions from cognitive and educational psychology. Psychological Science in the Public Interest, 14(1), 4-58. http://dx.doi.org/10.1177/1529100612453266

Ezeudu, F. O., \& Obi-Theresa, N. (2013). Effect of gender and location on students' achievement in chemistry in secondary schools in Nsukka local governmentarea of Enugu state, Nigeria. Research on Humanities and Social Sciences, 3(15), 50-55.

Kohlhaas, K., Lin, H. H., \& Chu, K. L. (2010). Disaggregated outcomes of gender, ethnicity, and poverty on fifth grade science performance. Research in Middle Level Education Online, 33(7), 1-12.

Kulasagaran, P. (2013, July 28). A transparent system needed. The Star Online. Retrieved December 26, 2013, from http://www.thestar.com.my/News/Education/2013/07/28/A-transparent-system-needed.aspx/

Malaysian Ministry of Education. (2012). Malaysia Education Blueprint 2013-2025. Retrieved December 14, 2013, from http://www.moe.gov.my/userfiles/file/PPP/Preliminary-Blueprint-Eng.pdf

Metallidou, P., \& Vlachou, A. (2010). Children's self-regulated learning profile in language and mathematics: The role of task value beliefs. Psychology in the Schools, 47, 776-788. http://dx.doi.org/10.1002/pits.20503

Muhamad-Ikhwan, M. S., Ong, E. T., \& Sadiah, B. (2009). Self-regulated learning: Gender differences in motivation and learning strategies amongst Malaysian science students. Retrieved December 14, 2013, from http://www.recsam.edu.my/COSMED/cosmed09/AbstractsFullPapers2009/Abstract/Science\%20Parallel\%2 0PDF/Full\%20Paper/S14.pdf

Mullis, I. V. S., Martin, M. O., Foy, P., \& Arora, A. (2012). TIMSS 2011 International Results in Mathematics. Chesnut Hill, MA: TIMSS \& PIRLS International Study Center, Lynch School of Education, Boston College \& Amsterdam. 
Nelson, D. M. (1996). Maya hackers and the cyber spatialized nation-state: Modernity, ethnostalgia, and a lizard Queen in Guatemala. Cultural Anthropology, 11(3), 287-308. http://dx.doi.org/10.1525/can.1996.11.3.02a00010

Ness, B. M., \& Middleton, M. J. (2012). A framework for implementing individualized self regulated strategies in the classroom. Intervention in School and Clinic, 47(5), 267-275.

Niemivirta, M. (1997). Gender differences in motivational-cognitive patterns of self-regulated learning. Paper presented at the Annual meeting of the American Educational Research Association, Chicago, IL.

Obrentz, S. B. (2012). Predictors of science success: The impact of motivation and learning strategies on college chemistry performance. Educational Psychology and Special EducationDissertations. Paper 77. Retrieved December 5, 2013, from http://scholarworks.gsu.edu/cgi/viewcontent.cgi?article=1078\&context=epse_diss

Oludipe, D. I. (2012). Gender difference in Nigerian junior secondary students' academic achievement in basic science. Journal of Educational and Social Research, 2(1), 93-99.

Olukemi, O. B. (1998). Ensuring Active Participation of Girl in Science and Technology, Plans Towards the year 200. Journal of Women in colleges of Education, 2(1), 117-119.

Pintrich, P. R. (2000). The role of goal orientation in self-regulated learning. In M. Boekaerts, P. R. Pintrich, \& M. Zeidner (Eds.), Handbook of self-regulation (pp. 451-502). San Diego, CA: Academic.

Pintrich, P. R., \& Zusho, A. (2007). Student motivation and self-regulated learning in the college classroom. In R. P. Perry, \& J. C. Smart (Eds.), The scholarship of teaching and learning in higher education: An evidence-based perspective (pp. 731-810). New York: Springer.

Pintrich, P. R., Smith, D., Garcia, T., \& McKeachie, W. (1993). Reliability and predictive validity of the Motivated Strategies for Learning Questionnaire (MSLQ). Educational and Psychological Measurement, 53(3), 801-813. http://dx.doi.org/10.1177/0013164493053003024

Radovan, M. (2011). The relation between distance students' motivation, their use of learning strategies, and academic success. The Turkish Online Journal of Educational Technology, 10(1), 216-222.

Schunk, D., \& Zimmerman, B. (2007). Influencing children's self-efficacy and self-regulation of reading and writing through modeling. Reading \& Writing Quarterly, 23(1), 7-25. http://dx.doi.org/10.1080/10573560600837578

Taylor, R. T. (2012). Review of the Motivated Strategies for Learning Questionnaire (MSLQ) Using Reliability Generalization Techniques to Assess Scale Reliability. Auburn University.

Tenaw, Y. A. (2013). Relationship between self-efficacy, academic achievement and gender in analytical chemistry at Debre Markos College of teacher education. African Journal of Chemical Education, 3(1), $3-28$.

Turingan, J. P., \& Yang, Y. C. (2009). A cross-cultural comparison of self-regulated learning skills between Korean and Filipino college students. Asian Social Science, 5(12), 3-10. http://dx.doi.org/10.5539/ass.v5n12p3

Usher, E. L., \& Pajares, F. (2008). Self-efficacy for self-regulated learning: A validation study. Educational and Psychological Measurement, 68, 443-463. http://dx.doi.org/10.1177/0013164407308475

Wolters, C. (1999). The relation between high school students' motivational regulation and their use of learning strategies, effort, and classroom performance. Learning and Individual Differences, 11, 281-299. http://dx.doi.org/10.1016/S1041-6080(99)80004-1

Zimmerman, B. J. (1989). Models of self-regulated learning andacademic achievement. In B. J. Zimmerman \& D. H. Schunk (Eds.), Self-regulated learning and academic achievement: Theory, research, and practice (pp. 1-25). New York: Springer.

Zimmerman, B. J. (2000). Attaining self-regulation: A social-cognitive perspective. In M. Boekaerts, P. Pintrich, \& M. Zeidner (Eds.), Handbook of self-regulation (pp. 13-39). Orlando, FL: Academic Press. http://dx.doi.org/10.1016/B978-012109890-2/50030-5

Zimmerman, B. J. (2001). Theories of self-regulated learning and academic achievement: An overview and analysis. In B. J. Zimmerman, \& D. H. Schunk (Eds.), Self-regulated learning and academic achievement: Theoretical perspectives (2nd ed.) (pp. 1-38). Mahwah, NJ: Erlbaum.

Zimmerman, B. J., \& Martinez-Pons, M. (1990). Student differences in self-regulated learning: Relating grade, 
sex, and giftedness to self-efficacy and strategy use. Journal of Educational Psychology, 82(1), 51-59. http://dx.doi.org/10.1037/0022-0663.82.1.51

Zimmerman, B. J., Bonner, S., \& Kovach, R. (1996). Developing self-regulated learners: Beyondachievement to self-efficacy. Washington: APA.

\section{Copyrights}

Copyright for this article is retained by the author(s), with first publication rights granted to the journal.

This is an open-access article distributed under the terms and conditions of the Creative Commons Attribution license (http://creativecommons.org/licenses/by/3.0/). 